\title{
Comparative analysis of nanotechnology awareness in consumers and experts in South Korea
}

This article was published in the following Dove Press journal:

International Journal of Nanomedicine

15 December 2014

Number of times this article has been viewed

\author{
Yu-Ri Kim' \\ Eun Jeong Lee' \\ Sung Ha Park ${ }^{2}$ \\ Hyo Jin Kwon ${ }^{3}$ \\ Seong Soo A An ${ }^{4}$ \\ Sang Wook Son ${ }^{5}$ \\ Young Rok Seo ${ }^{6}$ \\ Jae-Eun $\mathrm{Pie}^{7}$ \\ Myoung Yoon ${ }^{8}$ \\ Ja Hei Kim ${ }^{8}$ \\ Meyoung-Kon Kim' \\ 'Department of Biochemistry and \\ Molecular Biology, Korea University \\ Medical School and College, Seoul, \\ South Korea; ${ }^{2}$ Department of \\ Biochemistry, University of Bath, \\ Bath, UK; ${ }^{3}$ Department of Medical \\ Education, Korea University \\ Medical School and College, \\ Seoul, South Korea; ${ }^{4}$ Department \\ of Bionanotechnology, Gachon \\ University, Seongnam, Gyeonggi, South \\ Korea; ${ }^{5}$ Department of Dermatology, \\ Korea University Medical School \\ and College, Seoul, South Korea; \\ ${ }^{6}$ Department of Life Science, Institute \\ of Environmental Medicine for Green \\ Chemistry, Dongguk University, Seoul, \\ South Korea; ${ }^{7}$ Department of Food \\ and Nutrition, College of Science \\ and Engineering, Anyang University, \\ Anyang, Gyeonggi, South Korea; \\ ${ }^{8}$ Consumers Korea, Seoul, South \\ Korea
}

Correspondence: Meyoung-Kon Kim Department of Biochemistry and Molecular Biology, Korea University Medical School and College, Anam-Dong $5 \mathrm{Ga}$, Seongbuk-Gu, Seoul I35-70I, South Korea

$\mathrm{Tel}+82222866184$

Fax +8229230480

Email jerrykim@korea.ac.kr
Purpose: This study examined the need for public communication about nanotechnologies and nanoparticles by providing a comparative analysis of the differences in risk awareness of nanotechnologies and nanoparticles between consumers and experts.

Methods: A total of 1,007 consumers and 150 experts participated in this study. A questionnaire was prepared examining their awareness of nanotechnologies and nanomaterials and their view of the necessity for information and education about the latest nanotechnologies and nanomaterials.

Results: Our results indicated that the expert group recognized that they knew more than consumers about nanotechnology and that there was a need for relevant education in nanotechnology and nanomaterials among consumers. We found that the consumer group had a more positive attitude toward nanotechnology, even though they did not know much about it. Moreover, the consumer group was inconclusive about the type of information on nanotechnology deemed necessary for the public, as well as the suitable party to be responsible for education and for delivering the information.

Conclusion: An education and promotion program targeting consumers should be established to overcome the differences between consumers and experts in their awareness of nanotechnology. Specifically, the establishment of concepts for nanomaterials or nanoproducts is required immediately. With clear standards on nanomaterials, consumers can make informed decisions in selecting nanoproducts in the market.

Keywords: comparative analysis, survey, consumers, experts, nanomaterials

\section{Introduction}

Nanotechnology is perceived as a key emerging technology with great potential to generate new products in the market. ${ }^{1,2}$ New applications for nanotechnology extend into various areas, including biotechnology, electronics, drug delivery, cosmetics, and biosensors. ${ }^{3}$ With this rapid growth of nanotechnology products, concerns about human exposure to nanomaterials and their potential harmful effects on human health have increased recently. ${ }^{4}$ To address these concerns, a number of studies have examined the potential adverse effects of nanomaterials and nanoproducts. ${ }^{5-8}$ In addition, different institutions, including government bodies, research centers, universities, and industry, have shared significant resources to determine the potential effects of nanotechnology. ${ }^{9-12}$ However, despite these numerous research efforts, consumers, one of the main stakeholders, still lack knowledge and awareness of the exact effects nanotechnologies and their applications can have on their health and lives.

Several recent studies have examined the public perception of nanotechnology because this is one of the key factors, possibly influencing their advance. A US survey 
reported that most of the respondents $(80 \%)$ had heard either a little or nothing about nanoparticles. Although these respondents had limited knowledge of nanotechnology, most of them expected it to have more benefits than risks. ${ }^{13}$ Likewise, a study by the European Commission showed that the majority of respondents lacked knowledge of nanotechnologies. ${ }^{14}$ It was also found that the public in Europe had a less optimistic attitude toward nanotechnology than in the United States. ${ }^{15}$ In addition, Lee et al indicated that public awareness and knowledge of nanotechnology was low. ${ }^{16}$ On the basis of these and other survey studies, we concluded that the establishment of concepts for nanomaterials or nanoproducts for the public was urgently required.

It is widely recognized that communication of the scientific results of risk assessment to the public, especially a public that lacks familiarity with an emerging technology, needs the instillation of social trust. ${ }^{13,17,18}$ This implies that information on nanotechnologies and their applications could be best disseminated by people with experience and expertise in this field. Although previous studies have found that the perception of experts did not agree with public perception or societal attitudes, ${ }^{17,18}$ it was generally considered that experts' views on technology and its applications were key factors in influencing the implementation of this emerging technology. ${ }^{2}$ Therefore, a study on the awareness or perception of an expert group should provide the basis for deciding which perceptions would be needed among the different stakeholder groups. ${ }^{19}$

In this study, we examined how consumers and experts viewed nanotechnologies and their applications. We also asked them what should be considered when addressing the need for social consensus and education on nanotechnologies to reduce the difference in levels of awareness between consumers and experts.

\section{Materials and methods Participants \\ Customer sample}

A total of 1,007 randomly selected consumers aged from their twenties to their fifties participated in this research. They were balanced in sex, religion, residence, age, education, marriage, profession, and income. The expected error rate was $95 \%$, with a confidence interval of $\pm 3.09 \%$.

\section{Expert sample}

We carefully selected 150 experts who worked in the field of nanotechnology and nanomaterials in South Korea. The samples were randomly chosen from professors, researchers, government officials, industry workers, and civil campaigners. The expected error rate was $95 \%$, with a confidence interval of $\pm 8.0 \%$. A comparison of the characteristics of the consumers and the experts is shown in Table 1.

\section{Questionnaire and survey method}

For the consumer survey, we used a field survey method based on a structured questionnaire and a one-to-one interview. For the expert survey, we interviewed experts in their offices, using a structured questionnaire. The questionnaire for consumers was divided into six sections and contained approximately 19 different questions; 17 different questions according to subject were prepared for the experts. To compare the perceptions on nanotechnologies, we chose the following four common questions: 1) "Do you know

Table I Respondent characteristics

\begin{tabular}{|c|c|c|c|c|}
\hline \multirow[t]{2}{*}{ Classification } & \multicolumn{2}{|l|}{ Consumer } & \multicolumn{2}{|l|}{ Expert } \\
\hline & Frequency & Percentage & Frequency & Percentage \\
\hline \multicolumn{5}{|l|}{ Sex } \\
\hline Male & 505 & 50.1 & 90 & 60.0 \\
\hline Female & 502 & 49.9 & 60 & 40.0 \\
\hline Total & $\mathrm{I}, 007$ & 100.0 & 150 & 100.0 \\
\hline \multicolumn{5}{|l|}{ Age, years } \\
\hline $11-30$ & 331 & 32.9 & 15 & 10.0 \\
\hline $31-50$ & 406 & 40.3 & 79 & 52.7 \\
\hline$>50$ & 270 & 26.8 & 56 & 37.3 \\
\hline Total & $\mathrm{I}, 007$ & 100.0 & 150 & 100.0 \\
\hline \multicolumn{5}{|l|}{ Education level } \\
\hline Enrolled in or graduated from middle or high school & 601 & 52.2 & 0 & 0 \\
\hline Enrolled in or graduated from university & 228 & 19.8 & 28 & 18.7 \\
\hline Enrolled in or graduated from graduate school & 315 & 27.4 & 122 & 81.3 \\
\hline Total & 1,007 & 100.0 & 150 & 100.0 \\
\hline
\end{tabular}


about nanotechnologies, nanomaterials, and nanoproducts?"

2) "How do you consider each of following items, related to the safety and risk of nanotechnology, nanomaterials, and nanoproducts?" 3) "Do you need relevant information regarding nanotechnology, nanomaterials, and nanoproducts?" and 4) "Do you think promotion and education on nanotechnology and nanoproducts are necessary?"

\section{Statistical analysis}

Frequencies and chi-square tests were determined for each characteristic, with participants compared by sex, age, and education. A one-way ANOVA analysis and two independent sample $t$-test were performed to evaluate the significance of the differences between the means. In addition, to measure the responses, we used a 4-point Likert scale, ranging from 1 (do not know at all) to 4 (know very well) and from 1 (not at all) to 4 (very). All analyses were performed using SPSS (version 19.0; IBM Corporation, Armonk, NY, USA).

\section{Results \\ Differences in awareness of nanotechnologies, nanomaterials, and nanoproducts}

To determine the differences in awareness of the technology between the consumers and the experts, we analyzed their responses using a Likert scale. The Likert scale was divided and labeled as 4 points, where 4 would indicate "know very well". Analyses of the results showed that the expert group (2.74 \pm 0.650$)$ knew more about nanotechnologies than the consumer group (2.11 $\pm 0.573 ; P=0.000$; Table 2$)$.

\section{Differences in awareness of safety factors related to nanomaterials}

We analyzed the respondents' awareness on safety factors in dealing with nanomaterials by asking them to choose from the following comments: "Nano is safe for the human body", "Nano can be harmful for the human body", "Nano could have a negative effect on the environment", and "Social consensus about the safety of nanomaterials is needed". After

Table 2 Awareness of nanotechnology, nanomaterials, and nanoproducts

\begin{tabular}{llllll}
\hline & $\mathbf{N}$ & Average & $\begin{array}{l}\text { Standard } \\
\text { deviation }\end{array}$ & t-value & $P$-value \\
\hline Expert & 150 & 2.74 & 0.650 & & \\
Consumer & 1,007 & 2.11 & 0.573 & 11.260 & 0.000 \\
\hline
\end{tabular}

Note: Responses were measured on a 4-point Likert scale: I (do not know at all), 2 (do not know well), 3 (know well), 4 (know very well). the survey, we scored the responses in accordances from 1 (not at all) to 4 (very).

Our results revealed that the consumer group (2.91 \pm 0.779$)$ felt safer with respect to nanomaterials and nanoproducts than the expert group $(2.11 \pm 0.671)$ (Table 3$)$. We also found that the expert group had a more negative attitude toward nanomaterials and nanoproducts than the consumer group. For example, they thought that nanotechnology could be harmful for the human body $(3.08 \pm 0.740)$ and could be negative for the environment $(2.91 \pm 0.618)$ in comparison with the consumer group (2.18 \pm 0.719 and $2.20 \pm 0.759$, respectively). There was also a statistical difference in the perceived necessity of public consensus about nanotechnologies, with the expert group (3.53 \pm 0.665$)$ scoring higher than the consumer group (2.85 \pm 0.916 ; Table 3$)$.

\section{Degree of necessity of relevant information regarding nanotechnology, nanomaterials, or nanoproducts}

As shown in Table 4, there was a great difference in the extent to which the consumers and experts felt the need for accurate information about nanotechnologies. For example, most of the respondents $(90.7 \%)$ in the expert group answered that "they do need relevant information", but only a little more than half of the respondents $(59.1 \%)$ from the consumer group chose this response $(P<0.05)$. Moreover, consumers and experts had different opinions about the types of information necessary for nanotechnologies, such as concepts, effects, benefits, functions, performances, and types $(P<0.05)$. Our analyzed results showed that the believed degree of necessity of information on both the "effects of nano on the human body" (51.2\%) and the "benefit and functions of nano" (31.1\%) was higher among the expert group. However, the consumer group revealed no significant difference in the type of information they considered necessary (Table 5).

\section{Degree of necessity for the education and promotion of nanotechnology, nanomaterials, or nanoproducts}

In response to the question of whether "education and promotion on nano are needed", most of the respondents (98.7\%) in the expert group chose "Yes". In the consumer group, $70.7 \%$ selected "they are needed". Interestingly, $18.3 \%$ answered that they "do not know well" (Table 6). For the delivery of education and promotions, the expert group chose professionals (77.3\%), including professors, researchers and 
Table 3 Awareness of factors related to nanotechnology

\begin{tabular}{|c|c|c|c|c|c|}
\hline Related factor and group & $\mathbf{N}$ & Average & Standard deviation & $t$-value & $P$-value \\
\hline Safe for the human body & & & & -11.849 & 0.000 \\
\hline Expert & 150 & 2.11 & 0.671 & & \\
\hline Consumer & $\mathrm{I}, 007$ & 2.91 & 0.779 & & \\
\hline Harmful to the human body & & & & 13.070 & 0.000 \\
\hline Expert & 150 & 3.08 & 0.740 & & \\
\hline Consumer & $\mathrm{I}, 007$ & 2.18 & 0.719 & & \\
\hline Negative effect on the environment & & & & 11.498 & 0.000 \\
\hline Expert & 150 & 2.91 & 0.618 & & \\
\hline Consumer & $\mathrm{I}, 007$ & 2.20 & 0.759 & & \\
\hline Social consent is required & & & & 10.759 & 0.000 \\
\hline Expert & 150 & 3.53 & 0.665 & & \\
\hline Consumer & $\mathrm{I}, 007$ & 2.85 & 0.916 & & \\
\hline
\end{tabular}

Note: Answer was labeled using a 4-point Likert scale: I (not at all), 2 (not very), 3 (mostly), 4 (very).

specialists, nongovernment organizations (NGOs) (72.0\%), and central government (63.3\%), as suitable parties. The answers from the consumer group also included the central government (24.9\%), NGOs (21.4\%), and other professionals (16.5\%). International organizations (expert, $14.7 \%$; consumer, $13.5 \%$ ) scored lower than the media (expert, 30.0\%; consumer, $16.9 \%$ ) in both groups. However, we found that the rates of responses for this question were much lower in the consumer group than in the expert group (Table 7).

\section{Discussion}

The capability of nanotechnology in producing new manufacturing processes and products in vastly varied sectors from agriculture to medicine could create changes in society as a whole. ${ }^{3}$ Some recent studies and our survey have found that consumers had little knowledge or awareness of nanotechnology. ${ }^{20-24}$ Therefore, people with experience and expertise in the field of nanotechnology from research institutes, universities, industry, government, and NGOs should provide accurate information on nanotechnologies and their applications to the public. $^{2}$ In our study, we surveyed consumers and experts on their awareness of the risks and the

Table 4 Degree of the need for relevant information regarding nanotechnology, nanomaterials, or nanoproducts

\begin{tabular}{lllll}
\hline Group & Yes & No & Total & Pearson chi-square \\
\hline Expert & & & & $55.970^{*}$ \\
$\quad$ Case & 136 & 14 & 150 & \\
$\quad$ Percentage & 90.7 & 9.3 & 100.0 & \\
Consumer & & & & \\
$\quad$ Case & 595 & 412 & 1,007 & \\
$\quad$ Percentage & 59.1 & 40.9 & 100.0 & \\
Total & & & & \\
$\quad$ Case & 731 & 426 & 1,157 & \\
$\quad$ Percentage & 63.2 & 36.8 & 100.0 & \\
\hline
\end{tabular}

Note: $* P<0.05$. need for public education about nanotechnologies and then compared the differences between their responses.

We found that consumers and experts differed in their perceptions of nanotechnologies, nanomaterials, and nanoproducts. The awareness or understanding of nanotechnologies in the expert group was higher than the consumer group. Although consumers did not know much about nanotechnologies and nanomaterials, they perceived lower levels of risk from the technology than the experts. Furthermore, the experts had higher concern than the consumers and thought that more negative effects of nanotechnology could influence the human body and the environment. It was generally recognized that experts and the public had differences in their perceptions of risk. ${ }^{17,18}$ In contrast, a recent study by Siegrist et al on the differences in risk perceptions of the hazards of nanotechnology between the public and scientists reported that experts saw fewer risks than lay people. ${ }^{1}$ We speculate that this was because the experts had greater training and experiences in nanotechnologies than consumers. Similarly, Siegrist et al assumed that experts, unlike lay people, based their risk assessments on actual or perceived knowledge about nanotechnologies. ${ }^{1}$ Moreover, some studies on emerging biotechnology showed that even experts could have conflicting (or different) opinions. For example, Priest and Gillespie reported that scientists had a more optimistic view than the public, but Gunter et al revealed that scientists worried more about the consequences of biotechnology. ${ }^{25,26}$

Our results also indicate significant differences between the consumers and experts for the need for disseminating information and education on nanotechnologies and their applications. More than $90 \%$ of respondents in the expert group answered that they thought relevant information and education were needed. These experts selected "effects on the human body" and "the benefits and function of 
Table 5 Necessary information about nanotechnology, nanomaterials or nanoproducts

\begin{tabular}{lllllll}
\hline Group & Concept & Effects & Benefits and functions & Types & Total & Pearson chi-square \\
\hline Expert & & & & & & \\
$\quad$ Case & 27 & 107 & 65 & 10 & 209 & $65.462 *$ \\
$\quad \begin{array}{l}\text { Percentage } \\
\text { Consumer }\end{array}$ & 12.9 & 51.2 & 31.1 & 4.8 & 100.0 & \\
$\quad$ Case & 195 & 352 & 284 & 187 & 1018 & \\
$\quad$ Percentage & 19.2 & 34.6 & 27.9 & 18.4 & 100.0 & \\
Total cases & 222 & 459 & 349 & 197 & 1227 & \\
\hline
\end{tabular}

Note: The data include plural responses; $* P<0.05$.

nanomaterials and nanoproducts" as urgent categories and important information that the public should receive. In contrast, we did not find any differences in the type of necessary information selected by the consumer groups. Moreover, approximately $20 \%$ of the respondents in the consumer group did not even decide whether they needed education and promotion of nanotechnology. As consumers are unfamiliar with nanotechnology, we urgently need to prepare guidelines for nanoproduct labeling, and they should be in a form that consumers clearly and immediately understand. Even though nanoproduct labeling is a key information source for consumers, current labeling information is insufficient. For example, most consumers have not obtained this information about nanoproducts, and the information on nanoproducts labels is classified into benefits and effects, which makes it hard for consumers to understand. In relation to nanoproduct labeling, only European Commission regulation 1123/2009 of the European Council and Parliament in the case of cosmetics, in 2010 , clearly required the labeling of nanoenabled products. ${ }^{27}$ The International Organization for Standardization has been working toward an international labeling standard for nanotechnology, "Labeling of Manufactured Nano-Objects and Products Containing Manufactured Nano-Objects. ${ }^{28}$ At the international level, there was no other policy associated with nanoproduct labeling. ${ }^{29}$ If that the risk assessment of

Table 6 Degree of need for education and promotion about nanotechnology

\begin{tabular}{llllll}
\hline Group & Yes & No & $\begin{array}{l}\text { Do not } \\
\text { know well }\end{array}$ & Total & $\begin{array}{l}\text { Pearson } \\
\text { chi-square }\end{array}$ \\
\hline $\begin{array}{l}\text { Expert } \\
\text { Case }\end{array}$ & 148 & 2 & 0 & 150 & 53.799 \\
$\begin{array}{l}\text { Percentage } \\
\text { Consumer }\end{array}$ & 98.7 & 1.3 & 0.0 & 100.0 & \\
$\quad$ Case & 708 & 111 & 183 & 1,002 & \\
$\quad \begin{array}{l}\text { Percentage } \\
\text { Total }\end{array}$ & 70.7 & 11.1 & 18.3 & 100.0 & \\
$\quad$ Case & 856 & 113 & 183 & 1,152 & \\
$\quad$ Percentage & 74.3 & 9.8 & 15.9 & 100.0 & \\
\hline
\end{tabular}

nanomaterials is not properly performed, this labeling can help protect consumers without doubt of the effect of hazard warning on nanoproducts. Therefore, labeling information for nanoproducts should be designed to include nanomaterials which are added, safety measures, possible exposure routes, and disposal information. ${ }^{30}$

In choosing the appropriate agents or routes for delivering education and promotion about nanotechnology, the experts had higher trust in professionals, NGOs, and central government. Although we found the consumers also chose central government, NGOs, and professionals, their rates of response were very low in comparison with those of the expert group. We assumed that the consumers had lower conviction in these agents because they have not been exposed to relevant information about nanotechnology from various sources. This is because of the gap between the experts' and the public's perception of nanotechnology. To decrease this gap in perception, there should be an increased communication and understanding between the public and the experts on nanotechnology. In contrast, we interestingly found that international organizations scored lower than the media in both groups. Continuous strengthening of international solidarity might be helpful to overcome this lower awareness and confidence in international organizations, and it could also bring about international consensus on national policy on nanotechnology.

It is necessary to form a consultative group to grasp the public's perception and understanding on up-to-date research and depth of knowledge, as well as to form a possible and effective risk communication system for nanotechnology and nanoproducts. The public, the main perceivers of the dangers of nanotechnology, have the right to obtain all the necessary data and information for a better and accurate understanding of nanotechnology. In addition, the consumers of such information, including companies, scientific researchers, and the public, need to actively participate in the decision-making process. In earlier studies, it was indicated that the public reaction to nanotechnology could 
Table 7 Recognition of nanotechnology education and promotion, by reliability of nanotechnology information source

\begin{tabular}{|c|c|c|c|c|c|c|c|c|}
\hline Group & $\begin{array}{l}\text { International } \\
\text { organization }\end{array}$ & $\begin{array}{l}\text { Government } \\
\text { agency }\end{array}$ & Enterprise & NGO & Professionals & Media & Total & $\begin{array}{l}\text { Pearson } \\
\text { chi-square }\end{array}$ \\
\hline \multicolumn{9}{|l|}{ Expert } \\
\hline Case & 22 & 95 & 13 & 108 & 116 & 45 & 150 & $327.976 *$ \\
\hline Percentage & 14.7 & 63.3 & 8.7 & 72.0 & 77.3 & 30.0 & 100.0 & \\
\hline \multicolumn{9}{|l|}{ Consumer } \\
\hline Case & $|3|$ & 241 & 65 & 207 & 160 & 163 & 967 & \\
\hline Percentage & 13.5 & 24.9 & 6.7 & 21.4 & 16.5 & 16.9 & 100.0 & \\
\hline Total cases & 153 & 336 & 78 & 315 & 276 & 208 & 1,117 & \\
\hline
\end{tabular}

Notes: The data include plural responses. $* P<0.05$.

Abbreviation: NGO, nongovernmental organization.

be affected by how the government, NGOs, and industry dealt with issues. ${ }^{31}$ In particular, confidences and trusts in governmental agencies were strong predictors for the risk awareness of nanotechnology. ${ }^{1,32}$ Therefore, the way that regulation and education programs were managed by the government, NGOs, and industry should be reflected in the high levels of trust from consumers, established by their knowledge-based risk awareness. An education and promotion program for consumers should focus on how reliable relevant information could be easily communicated, considering the unfamiliar concepts and definitions of various nanotechnologies. According to results from scientific evaluations, the government should exercise tighter control over nanomaterials, and further social surveillance should be conducted in examining the levels of public understanding on the risks of nanotechnology and nanoproducts.

\section{Conclusion}

This study examined the differences in awareness of nanotechnology between consumers and experts for the first time in South Korea. We found that consumers had a more optimistic view of nanotechnologies and their applications, even though they had less awareness of them than the expert group. In addition, the majority of experts thought that relevant information and education were needed, but some consumers were undecided or realized the needs for awareness and education. Therefore, a risk communication system aimed at consumers of nanotechnology should be starting to recognize these multiple values and incorporate them into the decision-making process. Simultaneously, communications channels should be established and implemented to ensure continuous education about newly developing nanotechnologies and products.

\section{Acknowledgments}

This research was supported by a grant (10182MFDS991) from the Ministry of Food and Drug Safety in 2011.
This study was also supported by the Research-Driven Hospital Project of Korea University Anam Hospital, accredited by the Korean Government of Ministry of Health and Welfare in 2013.

\section{Disclosure}

The authors report no conflicts of interest in this work.

\section{References}

1. Siegrist M, Keller C, Kastenholz H, Frey S, Wiek A. Laypeople's and experts' perception of nanotechnology hazards. Risk Anal. 2007;27(1): $59-69$.

2. Gupta N, Fischer AR, van der Lans IA, Frewer LJ. Factors influencing societal response of nanotechnology: an expert stakeholder analysis. J Nanopart Res. 2012;14(5):857.

3. Manke A, Wang L, Rojanasakul Y. Mechanisms of nanoparticle-induced oxidative stress and toxicity. Biomed Res Int. 2013;2013:942916.

4. Bhattacharya K, Andón FT, El-Sayed R, Fadeel B. Mechanisms of carbon nanotube-induced toxicity: focus on pulmonary inflammation. Adv Drug Deliv Rev. 2013;65(15):2087-2097.

5. Kim YH, Park HW, Ryoo ZY, Lee H-S, Kim D-H, Lee S. Abnormal effects of unpurified and purified multi-walled carbon nanotubes in A549, Jurkat and THP-1 cell lines. Mol Cell Toxicol. 2012;8(1):103-112.

6. Jang YS, Lee EY, Park Y-H, et al. The potential for skin irritation, phototoxicity, and sensitization of $\mathrm{ZnO}$ nanoparticles. Mol Cell Toxicol. 2012;8(2):171-177.

7. Yim WC, Min K, Jung D, Lee B-M, Kwon Y. Cross experimental analysis of microarray gene expression data from volatile organic compounds treated targets. Mol Cell Toxicol. 2011;7(3):233-241.

8. Choi S-J, Lee JK, Jeong J, Choy J-H. Toxicity evaluation of inorganic nanoparticles: considerations and challenges. Mol Cell Toxicol. 2013;9(3):205-210.

9. Brossard D, Scheufele DA, Kim E, Lewenstein BV. Religiosity as a perceptual filter: examining processes of opinion formation about nanotechnology. Public Underst Sci. 2009;18(5):548-558.

10. Roco MC. Broader societal issues of nanotechnology. J Nanopart Res. 2003;5(3-4):181-189.

11. Roco MC, Bainbridge WS. Societal implications of nanoscience and nanotechnology: maximizing human benefit. J Nanopart Res. 2005;7:1-13.

12. Salerno M, Landoni P, Verganti R. Designing foresight studies for nanoscience and nanotechnology (NST) future developments. Technol Forecast Soc Change. 2008;75:1202-1223.

13. Cobb MD, Macoubrie J. Public perceptions about nanotechnology: risk, benefits and trust. J Nanopart Res. 2004;6:395-405.

14. Commission E. Eurobarometer 55.2. Europeans, Science and Technology. 2001. http://ec.europa.eu/research/press/2001/pr0612enreport.pdf. Accessed June 24, 2014. 
15. Gaskell G, Ten Eyck T, Jackson J, Veltri G. Imagining nanotechnology: cultural support for innovation in Europe and the United States. Public Underst Sci. 2005;14(1):81-90.

16. Lee CJ, Scheufele DA, Lewenstein BV. Public attitudes toward emerging technologies - examining the interactive effects of cognitions and affect on public attitudes toward nanotechnology. Sci Comm. 2005;27:240-267.

17. Kraus N, Malmfors T, Slovic P. Intuitive toxicology: expert and lay judgments of chemical risks. Risk Anal. 1992;12(2):215-232.

18. Savadori L, Savio S, Nicotra E, Rumiati R, Finucane M, Slovic P. Expert and public perception of risk from biotechnology. Risk Anal. 2004;24(5):1289-1299.

19. Besley JC, Kramer VL, Priest SH. Expert opinion on nanotechnology: risks, benefits, and regulation. J Nanopart Res. 2008;10(4):549-558.

20. Crow, MM, Sarewitz D. Nanotechnology and societal transformation. In Teich AH et al, editors. AAAS Science and Technology Policy Yearbook 2001. Washington, DC: American Association for the Advancement of Science; 2001;89-101.

21. Priest S. The North American opinion climate for nanotechnology and its products: opportunities and challenges. J Nanopart Res. 2006;8(5):563-568.

22. Pidgeon N, Harthorn BH, Bryant K, Rogers-Hayden T. Deliberating the risks of nanotechnologies for energy and health applications in the United States and United Kingdom. Nat Nanotechnol. 2009;4(2) 95-98.

23. Ronteltap A, Fischer AH, Tobi H. Societal response to nanotechnology: converging technologies-converging societal response research? J Nanopart Res. 2011;13:4399-4410.

24. Satterfield T, Kandlikar M, Beaudrie CE, Conti J, Herr Harthorn B. Anticipating the perceived risk of nanotechnologies. Nat Nanotechnol. 2009;4(11):752-758.
25. Priest SH, Gillespie AW. Seeds of discontent: expert opinion, mass media messages, and the public image of agricultural biotechnology. Sci Eng Ethics. 2000;6(4):529-539.

26. Gunter B, Kinderlerer J, Beyleveld D. The media and public understanding of biotechnology: a survey of scientists and journalists. Sci Commun. 1999;20:373-394.

27. European Parliament and the Council of the European Union. Regulation (EC) No 1223/2009 of the European Parliament and of the Council of November 30, 2009 on Cosmetic Products (recast). European Parliament and the Council. 2009. http://eur-lex.europa.eu/LexUriServ/LexUriServ. do?uri=OJ:L:2009:342:0059:0209:en:PDF. Accessed June 24, 2014.

28. International Organization for Standardization. Guidance on the Labelling of Manufactured Nano-objects and Products Containing Manufactured Nano-objects. 2010. Available from: https://www.iso.org/ obp/ui/\#iso:std:iso:ts:13830:ed-1:v1:en. Accessed November 4, 2014.

29. Gruère GP. Labeling nano-enabled consumer products. Nano Today. 2011;6(2):117-121.

30. Knébel S, Christoph M. "No Data, no Market?" Challenges to NanoInformation and Nano-Communication along the Value Chain. In: 5th International NanoRegulation Conference; November 25-26, 2009; Rapperswil, Switzerland. Available from: http://www.temas.ch/IMPART/ IMPARTProj.nsf/018B06B258A1B6A7C12576CC003C7D11/\$FILE/ NanoRegulation_5_Report_2009.pdf?OpenElement\&enetarea=02 . Accessed June 24, 2014.

31. Kasperson JX, Kasperson RE, Pidgeon N, Slovic P. The social amplification of risk: assessing fifteen years of research and theory. In: Pidgeon N, Kasperson R, Slovic P, editors. The Social Amplification of Risk. London: Cambridge University Press; 2003;13-46.

32. Siegrist $M$. The influence of trust and perceptions of risks and benefits on the acceptance of gene technology. Risk Anal. 2000;20(2):195-203.
International Journal of Nanomedicine

\section{Publish your work in this journal}

The International Journal of Nanomedicine is an international, peerreviewed journal focusing on the application of nanotechnology in diagnostics, therapeutics, and drug delivery systems throughout the biomedical field. This journal is indexed on PubMed Central,

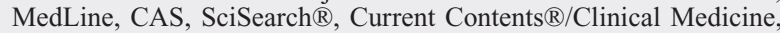

\section{Dovepress}

Journal Citation Reports/Science Edition, EMBase, Scopus and the Elsevier Bibliographic databases. The manuscript management system is completely online and includes a very quick and fair peer-review system, which is all easy to use. Visit http://www.dovepress.com/ testimonials.php to read real quotes from published authors. 